\title{
PERBANDINGAN JENIS HIJAUAN RAWA PADA PAKAN KOMPLIT GRANUL TERHADAP KANDUNGAN NUTRISI DAN KECERNAANYA
}

\author{
(Comparison Of Swamp Forages On Complete Granul Feeds To Nutrition Content And \\ Digestability)
}

\author{
Achmad Jaelani ${ }^{1}$, Abd. Malik ${ }^{1}$, Gusti Khairun Nimah ${ }^{\mathbf{2}}$ dan Muhammad Syarif Djaya ${ }^{\mathbf{1}}$ \\ ${ }^{1}$ Prodi Peternakan Fakultas Pertanian Universitas Islam Kalimantan Muhammad Asyad Al Banjari \\ ${ }^{2}$ Prodi Agribisnis Fakultas Pertanian Universitas Islam Kalimantan Muhammad Asyad Al Banjari \\ Jl. Adhyaksa No. 2 Kayu Tangi Banjarmasin 70123 \\ e-mail : ach_jaelaniborneo@yahoo.com
}

Article Submitted : 20-12-2018

Article Accepted : 31-01-2019

\begin{abstract}
The study aimed to analyze the type of swamp forage and its combination in granule complete feed products for their nutrient content and digestibility. This study have been done on Juli until September, 2018 in Field Laboratory at Bentok Kampung-Tanah Laut District. Randomized Block Design was used in this research with 3 treatments and 4 replications. Twenty goats aged 1.5-2 years with a weight ranging from $15-19 \mathrm{~kg}$ were used in this study. Data were analyzed by Analysis of varian and if there is significant difference then the Duncan Multi Range Test (DMRT) is continued. The results of the study show that swamp forage kalakai (Stenochlaena palustris), and purun tikus (Heleocharis dulcis Burm) significantly different to the crude protein content, crude fiber, crude fat, $\mathrm{ADF}$ and NDF fiber fraction. The complete granule feed on the basis of a combination of forage swamps and legumes affects the digestibility of organic matter and crude protein. The low content of tannin in swamp forages has not been able to optimally protect crude protein in complete granule feed.
\end{abstract}

Key word : tannin, protector, crude protein, swamp forages

\section{PENDAHULUAN}

Pemanfaatan sumber pakan lokal Kalimantan sangat penting dalam rangka meningkatkan efisiensi pakan. Sumber hijauan pakan yang banyak di daerah pasang surut/rawa Kalimantan belum banyak dimanfaatkan sebagai pakan ternak ruminansia adalah hijauan rawa. Selama ini keberadaan hijauan rawa lebih sering dianggap sebagai gulma karena dapat menyebabkan pendangkalan, yang berakibat pengurangan/ penguapan air dan unsur hara yang besar.

Menurut Musa (1988) habitat rawa yang ada di Kalimantan Selatan dapat dibedakan menjadi dua macam selama setahun, yakni saat level air pasang (high water period) dengan padang penggembalaan rumput terapung (floating meadows) dan pada saat air surut/kering (low water period), dimana keadaan padang penggembalaan mulai kering dan hanya bagian tertentu tergenang air. Hijauan rawa di Kalimantan memiliki karakteristik yang berbeda dengan hijauan lain. Produksi bahan kering hijauan rawa dengan sistem panen $2-3$ kali seminggu menghasilkan 44 ton/ha/th (Fahriani dan Eviyati, 2008), namun hijauan rawa umumnya tinggi akan serat kasar dan tannin. Hijauan rawa mengandung serat kasar 
$23-44 \%$ dan tannin yang berkisar $2-4 \%$ (Jaelani, 2018), adapun kandungan protein kasar dengan kisaran 16,2-17,7\% (Jaelani, 2018a)

Penggunaan kombinasi rumput rawa dan legume yang tinggi kandungan protein sebagai sumber pakan utama ternak kambing dapat memenuhi kebutuhan nutrisi untuk produkstivitas tinggi (Fujisaka et al., 2000), mengingat kandungan protein kasar rumput rawa tropis relatif rendah berkisar antara 4$9 \%$, sedangkan kebutuhan protein ransum kambing mencapai $14 \%$, sehingga perlu adanya kombinasi pemberian rumput rawa dengan legume. Namun keberadaan protein kasar yang ada pada legume harus diproteksi Salah satu cara adalah dengan menciptakan pelindung (protector) protein yang mampu melindungi protein dengan menggunakan tannin yang cukup banyak terdapat pada hijauan rawa. Tannin akan berikatan dengan protein di rumen sehingga menyebabkan protein terproteksi. Protein pada ternak ruminansia kecil umumnya terdegradasi di rumen sebelum mencapai abomasum, tempat terjadinya penyerapan zat-zat nutrisi. Akibatnya kecernaan protein akan berkurang karena rusak selama dalam perjalanan menuju abomasum, sehingga perlu adanya modifikasi agar kerusakan protein pada rumen bisa dikurangi. Disamping itu Tanin bermanfaat sebagai adstrigensia pada GI dan kulit, membantu proses metabolisme dari beberapa bagian tanaman, mengendapkan protein sehingga digunakan sebagai antiseptic, sebagai antidotum (keracunan alkaloid), sebagai reagen pendeteksi gelatin, alkaloid, dan protein.

\section{METODE PENELITIAN}

\section{Peubah yang diamati adalah :}

Pengamatan di dalam kandang percobaan :

1. Kecernaan bahan organik

$\%$ Kec. $\mathrm{BO}=\underline{(\Sigma \text { Konsumsi (BO) } \times \text { BO pakan })-(\Sigma \text { feses }(\mathrm{BO}) \times \mathrm{BO} \text { feses }} \quad \mathrm{X} 100 \%$

\section{Tempat dan Waktu}

Penelitian dilakukan selama dua bulan, bertempat di kandang ternak Laboratorium Lapang Faperta UNISKA Banjarmasin.

\section{Bahan dan Alat}

Pakan yang digunakan adalah hijauan rawa yang dikombinasikan dengan legume dalam bentuk granule dengan penyalutan tannin dari hijauan rawa terhadap legume indigo.

Bahan yang digunakan adalah kambing lokal umur satu tahun sebanyak 12 ekor, Hijauan rawa kalakai (Stenochlaena palustris), Purun tikus (Heleocharis dulcis Burm). Legume Indigofera sp., dedak padi, ampas tahu, tepung kanji, molasses, mineral. Ransum disusun isokalori dan isonitrogen. Adapun alat yang digunakan berupa mesin pencacah halus rumput, mesin granule, shaving matchine, sprayer

\section{Rancangan Percobaan}

Rancangan percobaan yang digunakan adalah rancangan acak kelompok dengan 3 perlakuan dengan 4 ulangan, dimana setiap ulangan terdiri dari 1 ekor kambing pedaging yang berumur 1,5 - 2 tahun atau dengan kisaran bobot badan 15-19 kg. Adapun total kambing yang digunakan adalah 12 ekor. Adapun perlakuannya adalah ;

G1 = Modifikasi Hijauan rawa kalakai + legume Indigofera

G2 = Modifikasi Hijauan rawa purun tikus dan kalakai + legum Indigofera

G3 = Modifikasi Hijauan rawa purun tikus + legume indigofera

$$
\Sigma \text { Konsumsi (BO) x BO Pakan }
$$


2. Kecernaan Protein Kasar

$\%$ Kec. PK $=\underline{(\Sigma \text { Konsumsi }(\mathrm{PK}) \times \mathrm{PK} \text { pakan })-(\Sigma \text { feses }(\mathrm{PK}) \times \mathrm{PK} \text { feses }} \quad \mathrm{X} 100 \%$ $\Sigma$ Konsumsi (PK) x PK Pakan

3. Kandungan Protein kasar

4. Kandungan Serat Kasar

5. Kandungan lemak kasar

6. Kandungan Bahan Organik

7. Kandungan Tannin Total

8. Kandungan ADF dan NDF (Van Soest, 1963)

Adapun untuk analisis proksimat metodanya sesuai Association of Official Analytical Chemist (AOAC) 1999

\section{Analisis Statistika}

Data yang diperoleh dianalisis dengan menggunakan Analisis varians, dan apabila menunjukan hasil yang berbeda maka dilanjutkan dengan uji berganda Duncan (Steel, R. G. D. and J. H. Torrie. 1993)

\section{Pelaksanaan}

Kambing ditempatkan dalam kandang metabolisma dan diberi pakan sesuai perlakuan Konsumsi pakan dicatat setiap hari. Pada hari ke -13 sampai dengan hari ke-18 total urin ( $10 \%$ dari volume) dan total fases $(10 \%$ dari berat feses $)$ ditampung dan diukur. Untuk pengambilan sampel urine wadah penampungan diisi $\mathrm{HCl} 10 \%$ sebanyak $(10 \mathrm{ml})$, pada hari ke18 sampel dikomposit, lalu diambil sub sampel untuk analisa kecernaan bahan kering, bahan organic dan kecernaan protein kasar..

\section{HASIL DAN PEMBAHASAN}

Berdasarkan hasil analisis laboratorium diperoleh kandungan nutrisi pakan komplit berbentuk granul masingmasing perlakuan disajikan pada Tabel 1.

Tabel 1.Kandungan Nutrisi Pakan Komplit granul dan nilai kecernaanya

\begin{tabular}{llccc}
\hline \multirow{2}{*}{ No } & \multicolumn{1}{c}{ Kandungan Nutrisi } & \multicolumn{3}{c}{ Perlakuan } \\
\cline { 3 - 5 } & Kadar air (\%) & G1 & G2 & G3 \\
\hline 1 & Serat Kasar (\%) & 7,54 & 6,18 & 7,68 \\
2 & $23,52^{\mathrm{a}}$ & $23,6^{\mathrm{a}}$ & $44,19^{\mathrm{b}}$ \\
3 & Protein Kasar (\%) & $16,12^{\mathrm{a}}$ & $16,57^{\mathrm{ab}}$ & $17,74^{\mathrm{b}}$ \\
4 & Lemak kasar (\%) & $2,29^{\mathrm{a}}$ & $3,04^{\mathrm{a}}$ & $1,34^{\mathrm{b}}$ \\
5 & Bahan Organik (\%) & $17,83^{\mathrm{a}}$ & $13,41^{\mathrm{b}}$ & $10,03^{\mathrm{c}}$ \\
6 & Tannin (g/100g)* & $0,035^{\mathrm{a}}$ & $0,046^{\mathrm{a}}$ & $0,075^{\mathrm{b}}$ \\
7 & ADF* $^{*}$ & $15,51^{\mathrm{a}}$ & $16,68^{\mathrm{ab}}$ & $20,55^{\mathrm{b}}$ \\
8 & NDF* $_{9}^{*}$ & $23,91^{\mathrm{a}}$ & $28,17^{\mathrm{ab}}$ & $33,75^{\mathrm{b}}$ \\
10 & Kecernaan Protein Kasar (\%) $^{*}$ Kecernaan Bahan Organik (\%) & $72,47^{\mathrm{a}}$ & $75,39^{\mathrm{b}}$ & $76,12^{\mathrm{b}}$ \\
\hline
\end{tabular}

Sumber : Hasil Analisis Laboratorium Pengujian Komoditi dan Lingkungan Balai Riset dan Standarisasi Industri (2018)

*Hasil Analisis Laboratorium Balai Penelitian Ternak Ciawi Bogor (2018)

\section{Hasil Analisis Proksimat (PK, SK, LK, BO)}

Berdasarkan hasil analisis ragam tidak menunjukan perbedaan yang signifikan terhadap kandungan kadar air, namun untuk kandungan serat kasar, protein kasar, lemak kasar, bahan organik menunjukan perbedaan secara sigifikan. Kandungan serat kasar pada perlakuan G3 (hijauan rawa purun tikus) menunjukan serat kasar yang sangat tinggi (44,19\%), dibanding perlakuakn G1 dan G2. Demikian pula dengan kandungan protein 
kasar ada kecenderungan meningkat dari G1 ke G3.

Terdapat perbedaan yang mencolok dari tumbuhan rawa, dimana hijauan yang banyak tumbuh dekat dengan air umumnya ditumbuhi hijauan purun tikus sedangkan yang agak jauh dari air umumnya ditumbuhi hijauan kalakai. Di areal lahan rawa umumnya air yang ada memiliki kandungan asam yang tinggi, disamping keberadaan zat besi yang cukup tinggi. Dari perbedaan ini tentu saja akan mempengaruhi terhadap komposisi botanis dan kandungan nutrisi.

Hijauan rawa yang dibuat pakan komplit memang menjadi kendala karena kandungan serat kasarnya yang tinggi. Untuk pakan komplit yang hijauan rawanya purun tikus (G3) menunjukan serat kasar yang tinggi. Dilihat dari kandungan protein kasarnya seluruh pakan komplit memenuhi kebutuhan protein kasar untuk kambing yaitu minimal $16 \%$.

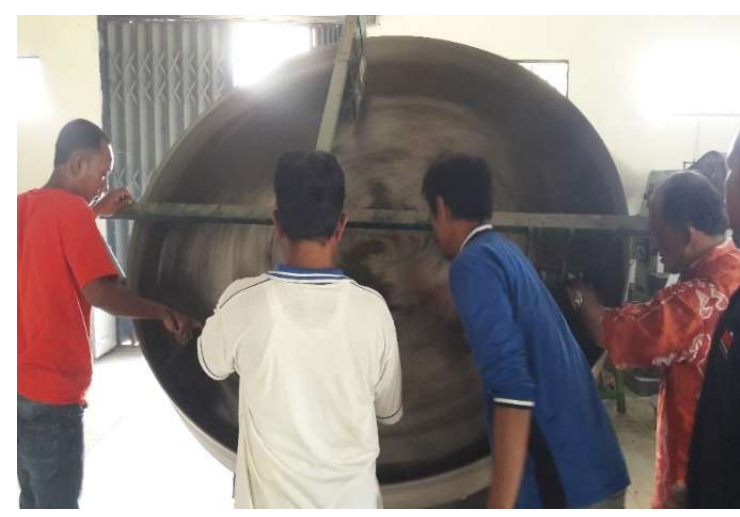

Gambar 1. A Proses pembuatan pakan komplit

\section{Kandungan ADF dan NDF}

Kandungan ADF

memiliki

kecenderungan meningkat dari G1, G2 sampai G3, meskipun G1 dan G2 tidak menunjukan perbedaan yang signifikan. Demikian pula hanya dengan kandungan NDF yang memiliki kecenderungan tertinggi diperoleh pada perlakuan G3. Hal ini berarti bahwa hijauan rawa purun tikus (Heleocharis dulcis Burm) memiliki kandungan ADF dan NDF yang lebih tinggi dibanding hijauan rawa kalakai (Stenochlaena palustris). Perbedaan fraksi potensial larut dan laju degadasi dipengaruhi oleh nutrient pakan. (Hadi dkk. 2011). Rohaeni et al., (2005) menyatakan bahwa kestabilan pertumbuhan tanaman dipengaruhi faktor-faktor lingkungan, terutama fluktuasi level air berpengaruh terhadap ekosistem rawa.

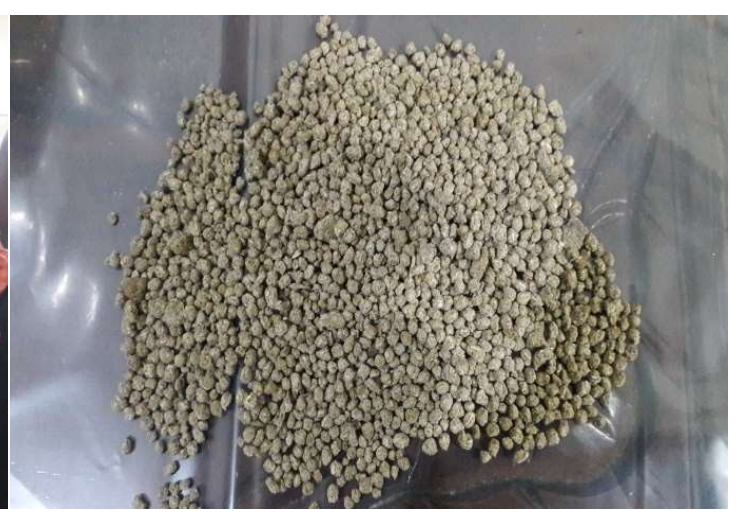

B. Pakan komplit granul yang sudah jadi

\section{Kandungan Tannin}

Tanin adalah beberapa antioksidan berjenis polifenol (yang mencegah atau mentralisasi efek radikal bebas yang merusak) yang menyatu dan mudah teroksidasi menjadi asam tanat. Asam tanat berfungsi membekukan protein yang berefek negatif pada mukosa lambung.

Dilihat dari kandungan tannin totalnya, ternyata baik hijauan rawa kalakai, purun tikus maupun kombinasinya menunjukan nilai tannin yang rendah (dibawah 1\%), sehingga pada perlakuan diberikan ekstrak tannin tambahan sehingga mampu secara optimal memproteksi protein. Berdasarkan penelitian Wahyuni dkk. (2014), bahwa penggunaan tannin 1\% yang dikombinasikan dengan 0,6 saponin dapat meningkatkan kecernaan bahan kering dan bahan organic serta meningkatkan kecernaan ADF dan NDF (Jayanegara dkk, 2014). 


\section{Kecernaan Bahan Organik}

Dilihat dari nilai kecernaan bahan organic $(\mathrm{KcBO})$ menunjukan hasil yang berbeda yata dimana yang meliki KcBO tertinggi diperoleh pada perlakuan G1 (pakan komplit granule dengan hijauan rawa kalakai) (58,76\%). Kecernaan bahan organik pakan komplit umumnya berkisar antara 62$78 \%$, namun apabila diklasifikasikan kedalam bentuknya untuk yang berbentuk pellet $60-65 \%$, cacah kasar $69-78$ dan tepung kasar 62-81 (Ginting, 2009)

\section{Kecernaan Protein Kasar}

Nilai kecernaan Protein kasar menunjukan adanya perbedaan yang signifikan, dimana perlakuakn G3 menunjukan nilai yang tertinggi $(76,12 \%)$. Kecernaan Protein kasar paka kambing yang diberi pakan komplit sangat dipengaruhi oleh satus fisiologis ternak, genotype, umur ternak, bentuk pakan komplit dan perbandingan roughages dengan konsentrat yang berkisar antara 0,25-3,0 (Ginting, 2009). Terdapat kecenderungan bahwa sampai tingkat tertentu kandungan tannin dapat memproteksi protein kasar yang masuk kedalam pencernaan kambing, sehingga kecernaan protein kasar lebih baik. Menurut Cakra dkk. (2014) diperoleh hasil kecernaan protein kasar 55,1 - 74,3\% pada kambing PE yang diberi kombinasi rumput dengan legume dan mineral molmix.

\section{KESIMPULAN}

1. Hijauan rawa kalakai (Stenochlaena palustris), dan purun tikus (Heleocharis dulcis Burm) dalam pakan komplit granul mempengaruhi terhadap kandungan protein kasar, serat kasar, lemak kasar, fraksi serat ADF dan NDF

2. Pakan komplit granul dengan basis kombinasi hijauan rawa dan legume mempengaruhi terhadap Kecernaan bahan organik dan Kecernaan protein kasar
3. Kandungan tannin yang rendah pada hijauan rawa belum mampu secara optimal dalam memproteksi protein kasar pada pakan komplit granul.

\section{UCAPAN TERIMAKASIH}

Ucapan terima kasih kami haturkan kepada Direktorat Riset dan Pengabdian kepada Masyarakat Kemenristedikti atas bantuan dana Hibah Penelitian Terapan Unggulan Perguruan Tinggi tahun Anggaran 2018.

\section{DAFTAR PUSTAKA}

Association of Official Analytical Chemist (AOAC) 1999 Official Methods of Analysis. Ed ke-16. Washington: AOAC International

Cakra, I G. L. O., Duarsa, M. A. P. dan Putra, S. 2014. Kecernaan Bahan Kering Dan Nutrien Ransum Pada Kambing Peranakan Etawah Yang Diberi Hijauan Beragam Dengan Aras Konsentrat "Molmik" Berbeda. Majalah Ilmiah Peternakan Volume 17 No. 1 tahun 2014. Fakultas Peternakan Universitas Udayana, Denpasar

Fahriani A. dan Eviyati. 2008. Potensi Rumput Rawa sebagai pakan ruminansia : produksi, daya tampung dan kandungan fraksi seratnya. Jurnal Indonesia Tropik Animal Agriculture. N0 33(4) desember.

Ginting, S.P. 2009. Prospek Penggunaan pakan Komplit Pada kambing Tinjauan manfaat dan Aspek Bentuk Fisik pakan Seta Respon Ternak. Wartazoa Volume 19 No. 2 hal 1-12

Hadi, R.F, Kustantinah dan Hartadi, H. 2011. Kecernaan In Sacco Hijauan 
Leguminosa Dan Non Leguminosa dlam rumen sapi Peranakan Ongole. Bulletin Peternakan Volume 35 (2), 79-85 Juni

Jaelani, A. Malik, A, Nimah, G.K, Djaya, M.S. 2018. Proceeding The $1^{\text {st }}$ International Conference on Food and Agriculture, Nusa Dua Bali, 20-21 Oct

Jaelani, A. Malik, A, Nimah, G.K, Djaya, M.S. 2018a. Prosiding Seminar Nasional VII Himpunan Ilmuwan Tanaman Pakan Indonesia, Hotel Tree Park Banjarmasin 5-6 November 2018

Jayanegara, A., Togtokhbayar, N., Makkar, H.P.S., Becker, K., 2008. Tannins determined by various methods as predictors of methane production reduction potential of plants by an in vitro rumen fermentation system. Anim. Feed Sci. Technol. 150: 230237.
Rohaeni, E. S., I. S. Danu, dan A. Subhan. 2005. Profil Usaha Ternak Kambing di Lahan Pasang Surut Kalimantan Selatan. Lokakarya Nasional Kambing Potong. Balai Besar Teknologi Pertanian Kalimantan Selatan. Hlm 165- 170

Steel, R. G. D. and J. H. Torrie. 1993. Prinsip dan Prosedur Statistik. Ed ke-2. Sumantri B, Penerjemah. Jakarta: Gramedia Pustaka Utama. Terjemahan

Van Soest, P.J., 1963. Use of detergents in the analysis of fibrous feeds. II. A rapid method for the determination of fiber and lignin. Journal of the Association of Official Analitical Chemists 46:828.

Wahyuni, I.M.D, Muktiani, A dan Christiyanto, M. 2014. Kecernaan Bahan Kering dan Bahan Organik dan Degradabilitas Serat pada Pakan yang Disuplementasi Tanin dan Saponin, Jurnal Agripet Vol. 14 No. 2 